\title{
The Personnel Administrator in University Libraries and in Business
}

Mr. Trent's interest in personnel administration has led him to trace out some comparisons which may be suggestive to librarians.

$\mathrm{T}_{\mathrm{t}}$ HE ROLE of the personnel administrator, within the narrow confines of this paper, is limited to the part he plays in the organization setup for carrying out the personnel policies of an institution. This narrows the present study to the authority centralized in the personnel officer and to the procedures through which he administers that authority.

There has long been a question as to what extent college and university libraries have availed themselves of methods used successfully in business organizations. To answer this, inquiries about their personnel practices were addressed to twentythree university libraries chosen primarily because they had relatively large staffs. The findings in the following paragraphs are based mainly on answers received from the sixteen libraries which were in position to cooperate. These libraries, on the whole, have been leaders in developing and improving library procedures. The questions asked them were worded with an eye to bringing out any similarity between library practices and those considered standard in the business field. No attempt was made to evaluate library personnel work; only processes for carrying out the work were investigated.

\section{The Personnel Administrator}

Essential to good personnel administration in business is the centralization of authority in one officer. $\mathrm{He}$ is a staff officer, whose duties are advisory, as distinguished from a line officer, whose duties are executive. It is generally believed that, since personnel administration covers all departments and all branches of service, the officer in charge should not be an executive through whom orders pass from head to subordinate but rather an advisory officer coordinate with the executives. The duties of this staff officer are those of a specialist who advises the executives, from the chief administrator down to the lowest supervisor, on all questions affecting personnel. The personnel administrator is a central clearing agent for aiding all departments in carrying out their responsibilities. He advises in establishing personnel policies and administers the procedures resulting from these policies, but he does not execute any decisions.

Such an officer was found in only three of the libraries studied, and it is possible that in one of these the personnel administrator is more of a line than a staff officer. The most frequent forms of centralization found are those in which the chief executive himself assumes all responsibility for personnel work or in which the chief executive delegates to an associate or assistant the personnel work 
among the lower grades.

Practices in the University of Illinois Library and Syracuse University Library appear to have been patterned after procedures which have proved valuable in business. At Illinois the work is administered by the assistant librarian for personnel, who devotes three-fourths time to the work with the help of two halftime assistants. This officer advises in establishing policies, sees that these policies are carried out, acts as a clearing house for all problems and decisions affecting personnel, and can work independently without waiting for an administrative request if it becomes necessary.

At Syracuse the assistant librarian is the personnel officer. He devotes only half time to the work and has no assistants, since the library staff is relatively small. $\mathrm{He}$ has the same authority as the one at Illinois. In both of these cases the authority is clearly defined and the position is almost, if not entirely, that of a staff officer.

The third library, which wishes to be anonymous, centralizes authority in the associate librarian. Here the scope of the work is not so clearly defined, and it seems probable that it is done mostly from the standpoint of an executive officer rather than as a personnel advisor. The same assumption holds true in the customary library plan where the chief executive, alone or with the associate or assistant librarian, assumes the duties. The advisory functions of the staff officer are likely to become intermingled with the executive functions of the line officer. This dual role theoretically might compel the executive to advise himself and then to turn quickly and execute his own decision.

In several libraries the university per- sonnel office assists in problems in the library. This might be satisfactory for clerical workers and students, but it is doubtful if it could be of value in dealing with the professional staff. In theory, since the library is a department of the university, its personnel problems should be handled uniformly with those of other departments. The other departments, however, commonly do not have the hierarchical scheme of administration which prevails in most libraries, and consequently their personnel problems may not be identical. If a qualified member of the university personnel staff could be assigned to work with the library, to study its problems, and to administer them separately, such a scheme would be practical. However, this is not done so far as could be ascertained from the replies.

Some libraries feel that size of staff is a factor in determining the plan of management. One administrator with a staff of almost two hundred states that he has intimate enough knowledge of his staff to make a personnel administrator unnecessary. However, the fact that Syracuse University Library, with a staff of 44 , and Illinois, which has a staff of 282 , both find a carefully worked out scheme feasible and useful, tends to show that size is not a decisive matter in personnel administration.

In the administration of policies established by the executives, with the advice of the personnel officer, the work is divided roughly into four main divisions-employment practices, follow-up records and training programs, factors affecting health and efficiency, and administration-staff relations. 'In all of these, according to approved business practices, the personnel officer advises, supervises, or administers the procedures. 


\section{Employment Practices}

In business one of the main duties of the personnel officer is to take the employment load off the chief executive. In most cases all applications are received in the personnel office, all interviews excepting those for executive officers are conducted there, and the majority of decisions as to employment and dismissal are made there. Even in filling executive positions, the personnel officer advises the administrator.

In the libraries studied, however, the general practice is for the chief librarian to interview and appoint the professional staff, while the associate or assistant librarian performs that function for the lower grades. Usually the head of the department involved is consulted before the appointment is made. The librarian of the University of Texas writes that ". . . it is our practice to have persons applying for .... positions, or under consideration for them, to be interviewed by, or their records inspected by, the associate librarian as well as by myself so that the benefit of two opinions is available. Frequently this is extended to unit heads."

\section{Follow-up Records and Training Programs}

Personnel administrators in business keep careful follow-up records of new employees and on the basis of this can recommend promotion, transfer, or dismissal. This is done in an objective way to balance the often too subjective appraisals made by the immediate supervisors. The importance of a follow-up record is that it enables the personnel officer to keep a constant check on the worker. As Isabella Brandow, instructor in personnel training at New York University, said at the Conference of Eastern
College Librarians in January, the new worker always has a feeling of elation, of enthusiasm, on beginning a job. That elation is bound to subside later and may be replaced by a feeling of having been forgotten or ignored. If, however, a follow-up system is maintained, such demoralizing factors can often be avoided. Follow-up records for the entire library staff are kept by the personnel officer at Illinois; by the librarian, acting as personnel officer, at Indiana University; and by the university civil service committee at Minnesota. The associate librarian at Texas maintains a follow-up of clerical and student assistants and pages. In the other twelve libraries, it is kept by division or department heads, if it is done at all.

Together with a follow-up system, a good training program is an incentive to the worker and makes him feel that he is of value to the organization. This has long been recognized in business, where much time and effort is spent on such programs. Another aspect of the matter was well brought out by Miss Brandow, who pointed out that the salary of even an unskilled worker will soon exceed the value of a typewriter. A typewriter generally is kept carefully covered and cleaned, and it follows that the worker, who represents a much greater investment, should not be neglected. Business organizations do not limit their training programs to beginners but continue to train workers as they progress to higher jobs. Department heads are also taught how to train those under them, since it is a recognized fact that a good department head is not necessarily a good teacher without supervision.

In most libraries the training program is not supervised by the personnel officer, although at Illinois he advises on training 
for promotion and transfer. At Johns Hopkins and the University of Washington the librarian himself advises in the program for training new assistants, while some other libraries have carefully worked out programs which are put into effect by department heads.

\section{Factors Affecting Health and Efficiency}

Health of employees is recognized as of great importance in business and industry. Physical examinations are frequently required at time of employment, and through these many mistakes in placement can be avoided. Fatigue studies and carefully controlled experiments have been made by many personnel departments to determine under what conditions employees are most efficient. Poor lighting and ventilation, crowded working conditions, and lack of rest periods, all have been proved to affect efficiency; and business generally is quick to correct adverse conditions.

Libraries do not appear to have any carefully thought out plans for solving these problems. Physical examinations are required in only five of the libraries questioned. Does this mean they are considered of no importance? Library buildings are notoriously bad in lighting, ventilation, and work space. William E. Mosher, in discussing personnel policy in libraries, ${ }^{1}$ suggests that fatigue studies and tests of lighting and humidity would show appalling conditions. To what extent the personnel officer tries to alleviate these conditions is not clear from the replies received, although in eight libraries supervision or control over physical working conditions is vested in the librarian or personnel officer.

1 Mosher, William
lightened Personnel Policy." "Imp'ications of an
En

lightened Personnel Policy." Library Journal 62:
$849-52$, Nov. 15, 1937. SEPTEMBER, 1944
Policies on rest periods and sick leave are usually determined by the university, although in three libraries the library personnel officer advises on these problems. The matter is handled in some libraries by the staff associations, as is true at the University of Washington, where the association has worked out a policy on rest periods and sick leave. Six libraries failed to answer the questions concerning the above subjects, which might lead to the conclusion that the matter receives little attention.

Closely allied with physical health is mental well-being. As bearing on this, the personnel officer in business is in a position to advise on savings and pension plans leading to financial security, which is an important factor in making a satisfied worker. He is also the adviser on vacations and leaves of absence. These matters are beyond the control of most libraries, since in the majority of cases the policy is established by the university.

\section{Administration-Staff Relations}

That human beings do not always agree is a fact readily accepted in business, where in many cases there are definite channels through which problems of maladjustment, grievances, and disciplinary matters pass to the personnel officer. This officer, from his position on the sidelines, as it were, can render a more impartial judgment than can an executive under whom disputants work. Only a somewhat detached observer can determine whether it is the supervisor, the type of work, or some other factor which causes the worker to operate inefficiently.

The personnel officers at Illinois and Syracuse, if they are staff officers, as it would seem, are in a position to arbitrate differences judicially. All complaints, 
grievances, and cases of maladjustment are cleared through their offices. Although most of the other libraries report that such cases are referred to the officer in charge of personnel, it would appear from the replies that it is because he is an executive rather than a personnel officer. This puts him in the position of being both judge and jury, and often prosecutor as well. The lack of grievance machinery would seem to indicate that librarians consider their staffs to be happy families, without human frailties.

One library reports that the university personnel office is always ready to listen to grievances and problems. If this office is effective, it must be far enough removed to avoid any suspicion of interest in the cases. It seems probable, however, that only the most serious matters would be carried that far.

\section{Should Libraries Adopt \\ Business Methods?}

From the foregoing summaries, it would appear that only two libraries have taken full advantage of the experience of business and industry in personnel administration, although many of the others have taken parts of the industrial system and fitted them into the traditional library organization. Which method produces the better results is not within the province of this paper to determine.

Conversations with librarians have shown that there is a general belief that the library staff, because of its training, interests, and general cultural background, does not need any kind of personnel system. In the few cases where a need has been conceded, it has always been limited to clerical and student assistants. It seems apparent that in some of the libraries concerned in this study the same attitude prevails.

Why should libraries not need a personnel system to assist in administration, to promote efficiency, and to smooth staff relations? Physical and psychological factors influence librarians as they do other types of workers. Purely personal disagreements between staff members may affect the work, and if one of the disturbing elements is a supervisor and the other one an assistant, serious difficulties can result. Librarians often work under pressure, especially at the present time, and nervous strain respects neither a college degree nor a cultured and bookish background. There are doubtless as many cases of maladjustment in libraries as in the world of business.

To adjust these personal relations, as well as other conditions which govern the efficiency of administration, it would seem advisable for libraries generally to reexamine their personnel practices. If procedures used successfully in business seem useful, consideration might well be given to the possibility of incorporating them in the postwar reconstruction of libraries which seems inevitable. 